\title{
Tadeusz Bodio
}

Faculty of Political Science and International Relations, University of Warsaw

Committee of Political Science, Polish Academy of Science (Poland)

ORCID: https://orcid.org/0000-0001-8873-7434

e-mail: tbodio@wp.pl

\section{Uzbekistan:}

\section{A State Undergoing Total Reconstruction}

\begin{abstract}
This study attempts to demonstrate the reform strategies implemented in the last three years in Uzbekistan. The author focuses on analyzing the implementation of five priorities of this strategy - the dialogue between the authorities and society, human resources and management system, economy and social sphere, security and foreign policy. He devotes a great deal of attention to present the image of the architect of these reforms - the president of the state. The author emphasizes that the style of exercising power, including the implementation of reforms by Shavkat Mirziyoyev, fits into the model of transformational leadership. It is a reforming, missionary, and servant (national) leadership tailored to the expectations and aspirations of the society, but also burdened with high risk, regardless of the starting conditions for the reconstruction of the state.
\end{abstract}

Keywords: Uzbekistan, Shavkat Mirziyoyev, leadership style, state reconstruction strategy, political dialogue, human resources and management system, economy and social sphere, security and foreign policy

\section{Introduction}

The dynamics of socio-political and economic changes in Uzbekistan have been surprising in recent years. It has started since 2016 with the end of the "era of I. Karimov", when the state was perceived as one of the most authoritarian regimes in the world. The changes concern all key areas of social life. One may even risk a thesis that the current Uzbekistan is a state "undergoing total reconstruction". The aim of that change is to dismantle the hitherto "national model of Uzbek nationality" in favor of a model corresponding to the standards of modern country and multiethnic Uzbek citizens' expectations and aspirations. 
It should be emphasized that in the assessment of the European Parliament these reforms comply with the European Union's strategy toward Central Asia ${ }^{1}$. Their discernible effects were an impulse for beginning negotiations between the EU and Uzbekistan in November 2018 on making a comprehensive and strengthened partnership and cooperation agreement that shall replace the document of 1999 (Sprawozdanie w sprawie zalecenia...., 2019).

The change of the model of Uzbek statehood is initiated from the top - by the ruling elites. Their main architect is President Shavkat Mirziyoyev. The effects of his three years reforming activity gain significant recognition in the Uzbek society. Public opinion polls conducted in the second half of December 2019 show that 96,3\% of respondents agree with the reform strategy proposed and realized by the President and his advisors (Сарымсакова, 2019). Such an extent of support seems unbelievable if compared to the rankings of leaders in European countries.

The President's strategy and its hitherto effects find recognition in the international arena. In 2018 the "StrategEast" Center (Washington), which promotes lawfulness and economic transformation among the states created after the collapse of the USSR, distinguished the Uzbek President with an award for the realized programme of reforms ("Народное слово", 2019). Also in 2018, Shavkat Mirziyoyev gained the second place among the most active leaders of the Commonwealth of Independent States. In December 2019 the weekly The Economist called Uzbekistan as the "Country of the Year", appreciating the dynamics and first results of activities undertaken by the new state authorities (Новости Узбекистана, 2019). The change in the information politics was also noticed. The Asia Journalist Association (focusing journalists from more than 20 countries, having headquarters in Seoul) acknowledged Shavkat Mirziyoyev as the continent's "Person of the Year" in the category "politics" (Новости Узбекистана, 2019), and the leading Turkish publishing house "Derin Ekonomi" counted the President to the "first ten" of world leaders having the biggest influence on events occurring in their regions (Корнилова, 2018). Also, at the beginning of 2020 President Shavkat Mirziyoyev was distinguished by influential in Central Asia the Cooperation Council of Turkic-Speaking States for outstanding contribution for the rejuvenation of the Turkic world (Interkomitet.uz, 2020). Granting him the award was connected e.g. with recognizing Khiva as the cultural centre of the Turkic World. There were much more of such and similar awards.

The recent years indeed reflect progress in the realization of reforms initiated by Shavkat Mirziyoyev, most of all in the areas of improving the separation of powers, fiscal policy, economic freedom and protection of private property, limiting bureaucracy, liberalizing

1 The article was written within the project entitled "European Union toward Central Asia - regional and international conditions" conducted at the Faculty of Political Sciences and Journalism at the Adam Mickiewicz University in Poznań (National Research Centre grant No. UMO-2014/15/B/HS5/01591). For more about the strategy of EU toward Central Asia states see: (Bodio, 2018). 
of socio-economic life, following the law and recognizing civic liberties, freedom of press, lawfulness and functioning of public security services.

New authorities make efforts for establishing dialogue with the society. They have limited censorship, fought with corruption, introduced regime without foreign currency, reformed banking and tax system, improved investment conditions, assigned attention to education reform and social protection of people, and conducted active foreign policy. It is worth to underline that these activities slightly increase the state's democratic index (Democracy Index). In 2016, Uzbekistan was classified at $158^{\text {th }}$ position. After two years of rules of Shavkat Mirziyoyev Uzbekistan has advanced to $156^{\text {th }}$ position from 167 countries of the world (Гуманитарный Портал, 2019). It was a noticeable achievement for the state that for many years has been classified at the very end of international democracy rankings. Also, it is worth noting that the increase of democracy index in Uzbekistan has happened in the period of evident inhibition of socio-political liberalization in other countries in the region. Unfortunately, according to the data from January 2020 it seems that Uzbekistan has lost one position in the ranking (Газета.uz, 2020).

The aim of this article is to reconstruct and analyze selected aspects of reform strategy realized in Uzbekistan ${ }^{2}$, and to demonstrate the type of leadership and reforms proposed by Shavkat Mirziyoyev - the second president in the history of independent Uzbekistan. The issue of changes within the political system of Uzbekistan was put to the margin because this subject is broadly investigated in another study of this project.

\section{Way to Presidency and First Decisions}

According to available and scarce biographical data, Shavkat Mirziyoyev, was born on July 24, 1957. He studied at the prestigious Tashkent Institute of Irrigation and Agricultural Mechanization Engineers. In 1981-1992 he worked there and defended a PhD thesis. Later he was appointed as a Deputy Rector of the Institute.

Shavkat Mirziyoyev began his political career in 1990 while he was still working in TIIAME, gaining a mandate to the Supreme Assembly of Uzbekistan. He continued parlia-

${ }^{2}$ An important problem of this investigation was access to the primary sources including official elaborates, reports and others, consisting analyses of political changes occurring in Uzbekistan. Worthy publications with analytical approach belong to the exceptions, especially those that investigate the categories of power, leadership and political elites. The lack of works presenting other views than these accepted by the authorities, concerning the realized reform strategy is tangible. Literature is dominated by superficial papers having advertising value, with many illustrations, reform promotion and the one narration. They are facilitated by formal institutions and organizations with significant research potential. Simultaneously, professional political analytics that supports opening public debate is underdeveloped. The reasons behind such a state of affairs is understandable. However, the deficit of such analytics (even in the sphere of economy), the difficult access to valuable political analyses and empirical studies do not serve the reform, dialogue, opening up for the world and making up the state's image in the long run. 
mentary work during next three terms of office, keeping the mandate until 2004. He also had several functions in state administration. In 1992, he became a hokim in Kuybishev (Mirzo Ulugbek) region in Tashkent. Two years later President I. Karimov appointed him as a hokim in Jizzakh region, and in 2001 in Samarqand region.

On December 12, 2003 he was appointed as the Prime Minister in the Cabinet of Ministers of Uzbekistan (Sputnik news.ru/Word, 2020, February 13). On September 8, 2016, several days after I. Karimov's death, he was appointed for the office of the President (Sputnik news.ru/asia, 2016, September 8).

Appointing Shavkat Mirziyoyev for that office was quite problematic. The Article 96 of the Constitution states that if a current president cannot fulfil his duties, his competences are transferred to the current Senate, along with the duty to organize elections in the period of three months (Муминов, 2016, September 10; Constitution.uz).

At the joint session of both parliamentary chambers the leader of the Senate resigned from the function of President's proxy, supporting his decision with the argument of the lack of appropriate experience and proposed the then Prime Minister, Shavkat Mirziyoyev, as his replacement. The members of the parliament unanimously voted for accepting this candidature, giving as an argument the need for maintaining stability, security and social order within the state. In media the situation was explained in many ways. Pro-government media indicated on the pragmatism and common sense of decision-makers in solving procedural issues. In turn, independent experts claimed that the struggle for the succession of power lasted for at least some time and that the candidacy of Shavkat Mirziyoyev was the result of compromise between the most influential political groups in Uzbekistan (Gazeta.ru, 2016, September 8; Сейидов, 2016, September 12). There are opinions that in the fight with Rustam Azimov - the Deputy Prime Minister and a pretender for the presidential office - the deciding meaning for Shavkat Mirziyoyev had the support given by Rustam Inoiatov, the chief of security services, in exchange for keeping him at this function (Саттаров, 2016, September 7; Семенов, 2018, March 2; CentralAsia, 2018, February 3; Nation News, 2016, September 8; TACC, 2016, September 2).

It may be hypothetically assumed that fast taking over the power, done without causing severe social tensions, by an experienced politician, for many observers seemed as a guarantee of implementing necessary reforms while maintaining stability and privileges of the existing arrangement within the ruling elites. Especially because Shavkat Mirziyoyev was belonging to the closest circle of I. Karimov's cooperatives, led the funeral ceremony of the former President, gave an encouraging speech about his predecessor's achievements and declared to continue his work ${ }^{3}$.

As a result, Shavkat Mirziyoyev has gained tremendous power. Temporarily fulfilling the presidential duties, at the same time he was the country's Prime Minister (until the

3 These declarations may be treated as tactical in the struggle for power. Strengthening his position, Shavkat Mirziyoyev distances himself from the concept of statehood realized by I. Karimov. 
next elections which meant the period of three months). Such a situation gave him a huge advantage over his rivals struggling for the office of president.

Several days after becoming the head of the state, on September 16, the Uzbekistan Liberal Democratic Party submitted Shavkat Mirziyoyev's candidacy for president. Exactly one week later the Central Election Commission of the Republic of Uzbekistan accepted it (Газета.uz, 2016, October 19). In the electoral campaign Shavkat Mirziyoyev was very active. First, he announced the realization of a set of socio-economic reforms, tending under the banner of "dialogue with the society" to mobilize the widest electorate possible; second - he started to fight against the symptoms of pathologies in state institutions; third - he started to build his own political support along with personal changes in the structures of power; fourth - he undertook many activities in internal and foreign policies which made him a more credible politician and potential president in the eyes of public opinion, which at the same time distanced him from and disturbed the privileged groups, including clerks, who became anxious about their future. During the electoral campaign Shavkat Mirziyoyev presented himself as a clever and experienced politician, able to use socio-technics to gain power, and as a pragmatic knowing the advantages and disadvantages of his own country, determined to implement necessary reforms also in the structures of state power.

In the presidential elections held on December 4, 2016 (it was the first time when an OSCE commission participated in Uzbek elections), Shavkat Mirziyoyev received 88,61\% votes (exactly 15906724 votes), and on December 13 was accepted his resignation from the office of Prime Minister. Next day Shavkat Mirziyoyev took an oath on the Uzbek constitution and Qur'an, officially overtaking the duties of the head of the state (Rambler. $\mathrm{ru}, 2016$, December 14). In his inauguration speech he announced that the main goal of his presidency is to build dynamically developing democratic country and that soon he will present a strategy of reforms for 2017-2021.

\section{Strategy for State Reconstruction}

On February 7,2017, so no more than two months after the swearing-in ceremony, Shavkat Mirziyoyev approved the reform strategy (LexUZ, 2017). Its adoption was preceded by numerous social consultations, with institutions and experts from abroad. The adoption of the strategy had a fundamental meaning for Uzbekistan, especially having in mind its backwardness and self-generating socio-economic problems threatening with a deep crisis that could cause unpredictable consequences.

The strategy assumes the realization of five priorities:

\section{A. Further improvement of public and social architecture:}

- increasing the role of parliament and political parties in deepening democratic reforms and modernizing the state;

- extending the competences of Oliy Majlis in the separation of powers;

- decentralization of the state; 
- reforming the system of governance and staff policy;

- transparency of the system of power and its social control at all levels;

- implementing efficient mechanisms of dialogue between state authorities and the society;

- strengthening the role of the institution of civic society and the means of mass communication;

\section{B. Strengthening the superior role of state and implementing judiciary} reform:

- democratization and strengthening of authority and independence of judicial institutions;

- improving material basis and implementing new information technologies;

- increase in the meaning of judges in controlling the organs of social order and conducted investigations;

- reconstruction of citizens' trust in courts;

- specialization and improvement of administrative, criminal, civil and economic legislation;

- strengthening guarantees for the protection of individual rights and liberties;

- development of legal aid institutions;

- cooperation with civil society organizations;

\section{Development and liberalization of economy:}

- strengthening the macroeconomic stability and dynamics of economic growth;

- institutional-structural reforms limiting the presence of the state in the economy;

- sustainable development of regions and cities with rational use of their economic and touristic potential;

- protection of private property and elimination of limitations for the functioning of private enterprises;

- efficient use of instruments stimulating economic growth - such as credit, insurance, leasing, etc.

- modernization and diversification of the most important sectors of economy;

- implementing international standards in domestic economy;

- gradual elimination of monopolies for goods and services;

- gradual implementation of mechanisms for the regulation of national currency exchange rate and market economy;

- stabilization of national currency exchange rate and prices;

- banking system reform;

- lowering taxes and an active investment policy;

- increasing the competitiveness of national economy; 
- development of transportation and communication infrastructure;

- development of free trade areas;

- implementing new technologies to the industry;

- intensive development of agriculture and the modernization of processing sector;

\section{Development of social sphere:}

- decreasing inflation and increasing the income of the people;

- elimination of unemployment;

- increasing professional qualifications;

- stimulate entrepreneurship, especially small and medium enterprises;

- increase in socio-professional activity of women and their participation in management;

- improvement of social protection and healthcare;

- realization of housing construction programmes;

- modernization of infrastructure and services that increase the people's quality of life;

- water and energy security;

- development of education system;

- improving youth policy;

\section{E. Strengthening internal and external security:}

- protection of constitutional order,

- realization of policy strengthening independence and sovereignty of the state;

- strengthening harmonious intercourse of ethnic groups and religious tolerance;

- creating safety, stability and good neighborhood area;

- creation of positive image of the state on the international arena;

- weakening the results of the Aral Sea crisis;

- designing new concept of foreign policy.

The indicated priorities were to be realized gradually in five years. For each of the stages there was elaborated a "roadmap" precising aims and tasks, indicating deadlines and subjects responsible for their realization. There was appointed the National Commission responsible for implementation of the Strategy; the Cabinet of Ministers was given the task of submitting annual reports on the advancement of reforms. The realization of the strategy was recognized as the most important task of all state institutions. 3,7 trillion soms and 8,3 billion dollars were deduced for that goal ("Tashkent Times", 2017, February 8; Regulation. gov.uz, 2019, October 22).

In 2017 emphasis was put on dialogue with the society. That is why it was called as the year of "dialogue between authorities, nation and its interests"; 2018 as the year of "support- 
ing active entrepreneurship"; 2019 as the year of "active investment and social development"; 2020 as the year of "science, education and digital economy".

It is worth noting that in October 2019, after lasting several months consultations, the President signed another document: Strategy of Complex Socio-Economic Development of the Republic of Uzbekistan until 2030. It expressed the will to continue reforms started in 2017, focusing on seven priorities, including: institutional changes, maintaining macroeconomic stability, improving economy's mechanisms, putting emphasis on innovative investments, upgrading industrial and communication infrastructure, effective managing human resources.

The strategy should be realized in three stages. In the first (2019-2021) there is planned to end the activities aimed at adapting economy to market mechanisms; in the second (2022-2025): to create structural changes making facilitating conditions for the dynamic development of economy; in the third (2026-2030): to converse from economy based on export and resources to innovative economic development based on the middle class and new technologies. The document includes precisely described "roadmaps" for the realization of particular stages of reforms in the most important economic sectors. Until 2030 it is planned to increase GDP per capita to USD 4538 (in 2018 it was USD 1533), which will require maintaining annual growth rate at 6,4\% (Regulation.gov.uz, 2019, October 22). The ambition of reformers is to include Uzbekistan to the group of economically developed states of the world 4 .

\section{Important Results of Three Years of Reforms}

\subsection{Dialogue between Authorities and Society}

Limitations in the area of human rights and civil liberties, omnipresence of spec-ops, mass media control, bureaucratism, corruption, censorship, weakness of civil society institutions, and other political pathologies have generated distance and distrust of society to authorities for many years. Shavkat Mirziyoyev was perfectly aware of these downsides which is why he treated establishing dialogue with the society and reforming system of power as the most important tasks of his presidency ${ }^{5}$. Yet in December 2016, three days after giving his oath, Shavkat Mirziyoyev gave a lecture on the occasion of $24^{\text {th }}$ anniversary of the adoption of the Uzbek constitution, in which he criticized the state officers for "they have forgotten how to

4 Ibidem. It is worth noting that in Uzbekistan there were published ca. 100 bills and decrees, and ca. 2000 other documents connected with the reform strategy.

${ }^{5}$ I claim that the dialogue with the society was also an element of struggle for power, reconfiguration of the existing set of political elites, among which there were numerous opponents of the President. By the occasion, the dialogue was in line with lowering social tensions and strengthening the position of the state's head. 
talk to the people", "recognize their problems, expectations and aspirations". He underlined that decisions concerning the state should be made based on direct dialogue with the people, considering their opinion, while the state officers of all levels should realize their basic role, and that the nation does not serve them; it is them who should serve the nation (Buxgalter. uz, 2016, December 7).

The realization of this task was connected with establishing relations between state authorities and the society, and with significant changes in the legislature. For this reason, there were implemented radical changes in the model of informing policy oriented on dialogue, studying and monitoring the public opinion, building a positive image of state authorities also beyond the borders of the country. Also, there were made significant institutional changes (e.g. the Uzbek Agency for Press and Information was transformed into the Agency of Information and Mass Communications under the Administration of the President of the Republic of Uzbekistan, while the Independent Institute for Monitoring the Formation of Civil Society was transformed into the Center for the Development of Civil Society), statistical services were reformed, and the control of mass media was limited. Public television was enriched with new information-education channels (e.g."Uzbekistan 24", "History of Uzbekistan"), tele-debates, round tables, etc. It has been started the open discussion about matters important for the people.

It is also worth noting that the cult of individual in mass media was prohibited. Organs of all levels of state authority was obliged to work with "open doors", conducting "rational dialogue" with people and treating it as one of chains of decision-making process.

It was proposed that analogue solutions were implemented by political parties ${ }^{6}$. Emphasis was put that dialogue methods were not façade and formalized, but efficient and based on the modern means of communication. The state authorities were obliged for running websites making contact with citizens easier. It was decided to create the system of digital offices collecting information about the activities of central, regional and local centers of state power. Also, the offices were designed to serve as means of legal aid, access to credible statistical data, consulting and considering citizens' complaints and their opinions on the functioning of the state.

An integral element of dialogue became a social assessment of the quality of state authorities' functioning. Also, these authorities were given a duty to periodically report the realized tasks ${ }^{7}$. It concerns e.g. the offices of prosecutors and domestic affairs which causes the resistance among bureaucrats who had operated in the shadows, avoiding social consultations and contact with media in the matters important for the people.

It is important that the process of building dialogue between state authorities and the society was started. It gives the first effects that facilitate e.g. better transparency of ruling,

${ }^{6}$ President, wanting to gain the support of citizens and political parties, undertook numerous activities strengthening their position in the political system and non-governmental organizations (Bowyer, 2018).

7 There was adopted a bill on the social control over state institutions activity. 
limiting the feeling of alienation, including anxiety of contacts with authorities, and better understanding of the reforms. The process is obviously still at the initial stages. It will be long and difficult (Мирзиёев, 2017, January 16), especially if one considers the heritage of previous political camp, bureaucracy and clerk's way of thinking, traditionalism and stereotypes, or the need for the further reforms in the political system.

In a nutshell, the try of establishing an authentic dialogue between the society and authorities undertaken by the President for the first time in the history of independent Uzbekistan is crucial for the realization of the reform strategy. The dialogue is treated as a method used for governing the state and increasing the participation of citizens in important decisions concerning the state. Considering the scope, costs and risks of the reforms, it would be difficult for the current authorities to legitimize reforms without departing from the "cabinet policy" and enabling the process of recovering the social trust.

\subsection{Staff and System of State Governance}

The political system of Uzbekistan was formed in the 1990s based mainly on Russian patterns and local tradition. In next years it was further consolidated. It featured with low flexibility and adaptation abilities. In this model the metaphor of "building strong country" legitimized strong power and, in consequence, a "police state" and the cult of individual. Numerous tries of democratizing the country undertaken in the last decades prolonged the vitality of the former political regime, simultaneously generating systemic problems, which was clearly visible on the example of the events in Andijan. For several decades, the model has placed a mark on local culture and political psychology. It created and consolidated the system of norms, institutions, mentality and behavior patterns, mainly among the people in power. These features became a severe barrier for the reforms, state governance and efficient staff policy. Both system and staff policy turned out to be destructive. For many years they have protected the anachronic political arrangements, strengthened the feeling of alienation, and blocked the development of civil society and real chance for dialogue with state authorities.

President Shavkat Mirziyoyev wants to change this state of affairs. Even as a temporal President he acted radically though rationally to reform the system of governance. Ordering the review of the current legal system, he started the process of staff and institutional change $e^{8}$, although not crossing the borders of state destabilization. On September 16, 2016, so several

${ }^{8}$ In the body of literature there may be encountered dubious views according to which initially, the personal changes were planned, agreed and not disturbing the balance between the main political and clan-regional groups (Игорь Панкратенко, Шавкат Мирзиеев: 100 дней в первом кресле Узбекистана, https://narzur.ru/shavkat-mirzieev-100-dney-v-pervom-kresle-uzbekist/; Бахтиёр Эргашев, Открытие Узбекистана. Итоги первого года президентства Шавката Мирзиёева, https://eurasia.expert/ otkrytie-uzbekistana-itogi-pervogo-goda-prezidentstva-shavkata-mirziyeeva). 
days after gaining presidential power, he signed an agreement on the organs of internal affairs (LexUZ, 2016, September 17). The document regulated and civilized the activity of public security services. He started the reform of judiciary (Sever, 2018). His "staff revolution" was widely commented. It assumed the replacement of high officers in prosecution, financial department and spec-ops. In time, the staff changes reached regions and bigger cities. In some departments many clerks were fired. The majority of administrative authorities was replaced. Also, court cases for corruption and abusing power have started. They included high officers in the organs of internal affairs, spec-ops, prosecution and financial department. The cases were accompanied by recruitments to the structures of power among youth. Some of them were advanced to very important state functions.

Staff changes were accompanied by the increasing criticism toward high state officers. For many of them - which was many times underlined by the President - the aim was not to serve their state and nation but their own interests, power and money. Particularly widely commented was the speech of Shavkat Mirziyoyev of January 16, 2017 at the extended session of government and prosecution (Мирзиёев, 2017, January 16; LexUZ, 2017, September 17). The President, giving concrete examples and data, decidedly blamed the chiefs of departments, also regional ones, for the lack of realization of tasks in 2016 and wasting, and even plunder of public property motivated with corruption, bureaucratic procedures, cabinet method of governing and lack of responsibility for these actions. The President said to the gathered officials that currently it is the life itself which determines the necessity of staff exchange at various levels. It is done to achieve the expected results. He added: "It is your luck that for now we do not have the sufficient number of employees. That is our main problem now". He outlined the need for the fundamental change of clerks' attitude toward their duties. He underlined that "the critical analysis, unconditional discipline and personal responsibility should become the common norm of activity of each official, no matter it is Prime Minister or hokim" (Мирзиёев, 2017, January 16).

The reform of the system of state governance and staff changes were realized in next months. There was undergoing decomposition of the old arrangement of power, in which a particular role was played by complex and omnipresent security services. Their works were led by gen. Rustam Inoiatov - co-creator of Uzbek authoritarianism (also called as the "Uzbek Beria" and the "main Chekist"), an influential person having tremendous property.

From the very beginning of his presidency, Shavkat Mirziyoyev has critically commented the activities of the security services, underlining that "they did everything they wanted", and their working methods sometimes were worse than those used by Stalinists. Starting from 2017, the roads of both politicians diverged, which resulted in the increasing negative attitude of security services toward the liberalization of public life. The services often blocked or sabotaged the reforms - the more often, the harsher were the criticism and limitations to their power and privileges. 
A breakthrough in relations between the President and Secret Service occurred on January $31,2018^{9}$, when during the meeting with their leaders Shavkat Mirziyoyev informed them about withdrawing R. Inoiatov from office because of his bad health condition (EADaily, 2018, January 31). The President ensured him and his family personal immunity, but not by a special decree, as the general wanted, but by appointing him as a personal advisor and senator, which was connected with receiving immunity.

Dismissing the chief of spec-ops by the President was widely discussed in the society, while the opinion of many observers of political scene was a turning point in the hidden struggle for power. Also, Shavkat Mirziyoyev began dismantling the structures of the National Security Service. The process of making the services "more humane" was tense and accompanied by numerous staff changes, arrests and investigations for abusing power and corruption. Ultimately, on March 14 the President signed a decree on transforming these services into the State Security Service, and a day later signed a corresponding bill (LexUZ, 2018, April 6). It introduced structural changes and limitations, put emphasis on collegial activities weakening the position of the chief of the security service. On the other side, it extended the prerogatives of the President who now appoints not only the chief but also his deputies. Supervisory functions of parliament and prosecution toward the security service were strengthened.

Reforms have not omitted the institution of President (LexUZ, 2017, March 1). On August 27, 2018, the institution was transformed into the Administration of the President of the Republic of Uzbekistan with significantly modified structure and tasks (TAG news. uz, 2018, August 28).

At the same time there were lasting works on improving the system of governing the state. In result, on September 8,2017, Shavkat Mirziyoyev signed a concept of administrative reform in the republic (LexUZ, 2017, September 8). It was a document of fundamental meaning for the reforms. It consisted of two parts: the first included the diagnosis of the current system of management and information. It was saying that the system is dysfunctional in terms of challenges resulting from the adopted strategy of reforms. Second part included tasks for building new, more effective and professional system of state authority, and indicated on mechanisms of fighting against corruption within these organs. In the new system emphasis is put on improving normative-institutional basis, decentralization, transparency and innovativeness of governance, efficient functioning coordination between

9 According to Usman Chaknazarov, yet in January 9,2018 R. Inoiatov informed leaders and officers of the National Security Service about his resignation from the function due to his health condition and that he will give the same resignation to the President, and propose him "not to destroy 25 years of achievements". Next day, during the meeting with the President he asked for granting him, by a special decree, immunity for him and his family. Also, he criticized the President's approach toward the services. Shavkat Mirziyoyev, however, asked him for staying on duty until finding his successor (Усман Хакназаров: Председатель СНБ Рустам Иноятов объявил о своей отставке, http://uzxalqharakati.com/ru/archives/15892). 
central and regional power, gradual extension of self-governments' competences, elimination of overlapping institutions, fight against bureaucracy, strengthening mechanisms ensuring civic rights and liberties, and social control over state institutions, and the implementation of transparent model of making career within public service. Also, there was elaborated a roadmap of the reforms which is constantly monitored and amended ${ }^{10}$.

In 2017 there was elaborated the draft of bill on the state service which was to create the outline for the professional public service. The bill has not been adopted yet. The main controversies connected with it concern: a) introduction of duty to submit unitary property declarations by the people in power and their families (starting from the President and Prime Minister, ending at common clerks); b) separation of political and administrative spheres in state governance; $c$ ) creation of mechanisms of prevention against entangling administrative services in various conflicts of interests (Axbor UZ, 2019, May 25). Eventually, at the end of 2019, within the programme of fight against corruption, there was made a decision to gradually implement the system of income, property and expenditures in the forms of annual declarations for the particular groups of clerks and their families. However, only a part of these declarations will be published. This system should be implemented gradually in the period of three years, starting from January 2020. In the first year the duty to submit declarations was imposed on deputy Prime Ministers, ministers, a part of presidential administration and directors of public enterprises (UZNews, 2019, October 11).

Although changes in the system of governance and staff policy bring expected results, they still remain the key challenges conditioning the success of the reform strategy. It is seen by the President himself who assessing the realization of reforms in the first half of 2019, ascertained that the current condition of staff of state apparatus, their professionalism and loyalty still remain the biggest threat for Uzbekistan (CentralAsia, 2019, August 18).

\subsection{Economy and Social Sphere}

"The Uzbek model of economic development" realized from the beginning of the 1990s was grounded in the command-and-distribution system. In general, it was Russian model of economy, socially oriented, de-ideologized, recognizing the primacy of economy over politics,

${ }^{10}$ A result of that monitoring was the creation of numerous legal acts that improve the system of governance, e.g. О дополнительных мерах по совершенствованию деятельности кабинета министров Республики Узбекистан, https://lex.uz/ru/docs/4186000; О мерах по дальнейшему сокращению бюрократических барьеров и внедрению современных управленческих приниипов в деятельность государственных органов и организаций, https://lex.uz/docs/4634625; Указ Президента Республики Узбекистан О мерах по кардинальному совершенствованию кадровой политики и системь государственной гражданской службы в Республике Узбекистан, https:// lex.uz/docs/4549993; Постановление Президента Республики Узбекистан О внедрении качественно новой системь организации работы Правительства Республики Узбекистан, https://nrm. uz/contentf?doc=577449_\&products=1_vse_zakonodatelstvo_u-zbekistana. 
with centralized governance and gradually implementing market mechanisms. It should be realized on the evolutionary way, consider local characteristics, way of life and tradition (Bodio, 2001, pp. 22-23; Star, 2018). Based on lasting 25 years state transformation it can be concluded that the realization of that model has led to stagnation and regression, threatening an economic disaster (Kun.uz/Ru, 2018, May 5). A possible solution to the problem was a fundamental and expensive transformation of economic system.

The strategy realized by President Shavkat Mirziyoyev since 2017 assumes a gradual realization of structural reforms with maintaining macroeconomic stability and high pace of development. In general, the reforms are directed to dismantle the command-anddistribution system, limit monopolistic state's position on the market, and to implement market mechanisms. They include legislature, institutions, finances, market, system of governance and people's mentality, stimulating entrepreneurship, fight against "gray zones" (estimated for $50 \%$ of GDP; $156^{\text {th }}$ position for 176 possible), etc. Within the reforms, huge emphasis is put on sustainable and innovative development of socially oriented economy, integrating with international surrounding. A priority is departing from exporting resources and half-products in favor of fully-developed ones with high added value (Spot, 2019, February 14).

The set of economic reforms is extensive. The analysis of available sources on their realization within the last three years has shown progress in terms of: adjusting law-making and official institutions to the standards of market economy; implementing digital technologies into management systems; economic monitoring and rebuilding statistical services; creating sterling market of goods and services; rationalizing the distribution of budget assets; integrating with international financial market; restructuring and diversifying banking system; converting national currency on the market principles; creating beneficial conditions for foreign investors; liberalizing prices and simplifying tax system; increasing economic selfreliance of regions; improving tax system and budget services; reforming system of education with considering the needs of the job market; social and professional activizing women and youth; modernizing communication and transportation infrastructure; eliminating corruption; developing entrepreneurship and small enterprises; and improving credit policy.

Protectionism, export licenses and subsidizing public companies were limited. Also, the changes included: lowering taxes (including customs tariffs), simplifying VAT return procedure, introducing incentives for business activity, creating special economic areas, elaborating motivating instruments for small and family companies, introducing twoyear moratorium for supervising these companies, implementing visa-free regime for 86 countries, civilizing Uzbek's labor migration to Kazakhstan, Russia and other countries (Tsereteli, 2018).

A lot of attention is paid to investment policy which, together with commercial enterprises, is the drive of reforms. In rankings Uzbekistan was counted as one out of ten countries making the friendliest conditions for investment. For the first time in the history of the 
republic euro-obligations worth USD 1 billion had been introduced to the market (Spot uz/ $\mathrm{ru}, 2019$, February 14). Reforms were started in the areas of oil, gas, energy, industry and agriculture. Tourism was intended to transform into the strategic sector of economy.

The initial data given by the State Committee of the Republic of Uzbekistan on Statistics in January 2020 confirm that the realized reforms bring significant results, despite they encounter numerous difficulties. According to them, in 2019 GDP increased of 5,5\% (in 2018: 5,1\%). There was noted an increase of income per capita - USD 1741 (in 2018: USD 1533). Budget deficit equals to $1,1 \%$ GDP. Comparing with 2018, there was increase of public expenditures for the planned reforms of $33,95 \%$ but also significantly (37\%) increased the investments' share in the budget (Meliev, 2019, December 13; Вестник Кавказа, 2020, January 27; Novosti Uzbekistana, 2020, January 20). Investments reached the level of USD 21 billion. Let us add that it is forecasted that in 2020 there will be further inflow if investments estimated for USD 7,1 billion - which is $25,8 \%$ of GDP (in 2018-19,8\%), with slight increase of gold reserves (USD 27,7 billion) despite selling 6 tones at the international market. There was increase of real income of $6,5 \%$ but also prices - 20\% (in 2018 this rate was 27\%). Inflation reached 15,2\% (Новости Узбекистана, 2020; КB, 2020, January 28). According to the last report of the World Bank, in the ranking "Doing Business" Uzbekistan advanced to $69^{\text {th }}$ place out of 190; in 2017 it had $86^{\text {th }}$ position (The World Bank, 2020, p. 4).

The realization of reforms in 2017-2019 had its own dramaturgy since numerous threats have shown up. However, the achieved results seem to indicate that the psychological barrier connected with their risk, break of macroeconomic stability and state security was crossed. On January 24, 2020, in his address to the members of the parliament, President Shavkat Mirziyoyev assessed the extent of reform realization and declared: "the fear or previous years has gone". He added: "Our nation should know that there is long and difficult road ahead (Правда Востока, 2020, January 25). In his view, many problems of forming market economy (concerning property issues, implementation of market principles to managing state assets, eliminating monopolies on the market and increasing its competitiveness, upgrading communication and transportation infrastructure, diversification of industry, creation job positions and increasing their efficiency, improvement of export and import policy, tax system, lowering inflation, and counteracting gray zones) were not solved ${ }^{11}$. In 2020 emphasis should be put on reforms in the areas of science, education and "digital economy".

According to official data the society supports the politics of reforms. From the studies conducted in December 2019 it seems that $83,4 \%$ of respondents positively asses the

11 According to the data of Ministry of Finances from January 2020, only 4,6 out of 13 mln working people pays income tax. In the republic there is unofficial job market. In result, taxes from 4,6 mln people had to suffice for 3,3 mln retired people (Джамшид Кучкаров: Из 13 млн. трудоспособных людей налог платят лишь 4,6 млн. https://uzreport.news/society/djamshid-kuchkarov-iz-13-mln-trudosposobnih-lyudey-nalog-platyat-lish-4-6-mln). 
liberalization of economy, increasing its competitiveness and creating conditions for the development of private enterprises. $57,8 \%$ of them noticed a positive influence of reforms on their quality of life (Сарымсакова, 2019, December 20).

Hitherto effects of the reforms in Uzbekistan have gained a positive assessment of international institutions, including the International Monetary Fund, the World Bank, the European Bank for Reconstruction and Development, the Asian Development Bank, and the Islamic Development Bank (Uzbekistan - Toward a New Economy..., 2019; РЕСПУБЛИКА УЗБЕКИСТАН КОНСУЛЬТАЦИИ..., 2019) ${ }^{12}$. The assessment contributes to the increase of Uzbekistan's positive international image, business trust and investments. Reports of these banks also include recommendations indicating e.g. the need for improving macroeconomic policy in terms of consolidation and rationalization of budget expenditures, improving fiscal and credit system, and the reconstruction of banking system (in which $2 / 3$ are public banks and their assets) with emphasis on creating commercial banks with international capital.

As mentioned, the reforms also have their dramaturgy connected with their vast costs borne by the citizens. Uzbeks are classified to the group of the poorest people in the world. Majority of them has problems with ensuring themselves basic products. In January 2020 authorities officially admitted that 5 million people live in poverty (Review.uz, 2020, January 27). Salaries, pensions, benefits for disabled, unemployed and other social groups are $10 w^{13}$. In 2019 an average monthly salary in public sector was estimated for USD 130, while the minimal for USD 46-48; financial support for disabled and unemployed for USD 46 (Migrant Info, 2019, November 24; Kun.uz, 2020, January 27). Employment is one of the most important tasks for the reformers. Uzbekistan is a country of youth (ca. 50\%). Each year the job market is entered by several hundred thousand young people who do not find job. In official data it was noted that unemployment among persons below 30 maintains at 15,3\%, women - 12,9\% (EADAILY, 2019, January 29). Increase in unemployment and low salaries result in mass labor migration, especially among young people with higher education.

Empirical studies show that in 2019 Uzbeks particularly felt the results of inflation and price increase among groceries (meet, milk products, fruits and vegetables), daily products, and medicine. They also indicated on difficulties with housing and the need for improving healthcare system. On the other side, they noticed the improvement of infrastructure: kindergartens, schools, their equipment, etc. (Сарымсакова, 2019, December 20). Other

12 In January 2020 there was published a report of analytical group of the United States Congress in which the economic transformation of Uzbekistan was assessed positively (Конгресс США признал эфбективность реформ в Узбекистане, https://uzdaily.uz/ru/post/48897).

13 A significant role in helping these people is played by Mahallah. It is a traditional self-government institution, a neighbor's community, which is an important element of life for all Uzbeks. In January 2020 the President announced the creation of the Ministry of Family and Mahallah (Президент Узбекистана, 2020; Махалля...,2016). 
surveys show that $58,5 \%$ of Uzbeks have difficulties with access to potable water and gas, $60 \%$ claims that there are problems with the access to hot water, and $70 \%$ complains on heating their flats (Росбалт.RU, 2017, July 11).

Expenditures for social policy in Uzbekistan absorb 50\% of budget (UzNews, 2019, November 2019), which does not compensate needs anyway, especially among the poorest citizens. Such situations usually result in the feeling of exclusion, alienation, another waves of labor migration and the lack of permission for radical reforms which, in the view of these people, deepen the social divisions. Therefore, it is understandable why social policy was recognized as one of the most important priorities for $2020^{14}$.

\subsection{Foreign Policy and Security}

President Shavkat Mirziyoyev made a radical turn in foreign policy. He broke up with selfisolation through opening up the state for globalizing world, and he put emphasis on building trust and prestige of Uzbekistan in the international surroundings. Mirziyoyev ordered to elaborate new concept of foreign policy ${ }^{15}$, maintaining only several pillars of the previous period concerning national security (prohibition of establishing foreign military bases on the territory of Uzbekistan, participation in political-military alliances, conflicts and foreign missions ${ }^{16}$. He has introduced structural and personal changes in the department of foreign affairs, and he has established cooperation with international financial organizations. He actively acts e.g. at the forum of the United Nations, the Shanghai Cooperation Organization, and the Commonwealth of Independent States. In 2020 Uzbekistan was leading the works of the latter. Also, there is ongoing mentioned dialogue with the European Union on the content of the agreement on strengthened partnership and cooperation (Sprawozdanie...2019, March 26). The EU, similarly to the US, supports the striving of Uzbekistan for joining the WTO.

Led by national interests, the President concludes sustainable politics with regional powers (Russia, China, the US and others). He rejects the tries of entangling Uzbekistan into a "geopolitical game" played by these powers. Cooperating with Turkey, he acts for improving political, economic and cultural relations with Turkish language nations. In relations with India, Japan, South Korea and others he made significant investment and

14 In the Address by the President from January 2020 it was indicated that along with international institutions there will be prepared the first poverty alleviation programme (Послание Президента Республики Узбекистан (25.01.2020).

${ }^{15}$ Local media already informed about the elaboration of the concept's project however it is probable that it has not been accepted yet. In any case, it is not present on official websites, including ministerial ones.

${ }^{16}$ In January 2018 the President signed an act on new military doctrine outlining the principles of protecting national security (Об Оборонной доктрине Республики Узбекистан, https://lex.uz/ docs/3495906). 
commercial achievements. He is engaged in solving the conflict in Afghanistan which was confirmed in 2017 by the visit of that country in Tashkent.

Uzbekistan's foreign activity is proven, for instance, by published data which show that only in 2019 Uzbek diplomatic services organized 1200 business meetings and 29 intergovernmental sessions. Uzbekistan was visited by 3000 foreign delegates and hosted 1100 financial and business delegations (МИД Узбекистана, 2019, December 31). These activities have brought huge investments, hundreds of projects and gaining new directions for export. Only in 2019, the commercial exchange of Uzbekistan noted 26\% increase (USD 42 billion), export noted 28\% increase (USD 17,9 billion), and import 25\% (USD 4,8 billion). According to the available data, in 2019, 2700 Uzbek companies began to export their goods (Reviw.Uz, 2020).

It is worth to underline that Uzbek reforms were positively addressed by the Polish economy. In 2018 there was 84,7\% increase (USD 241,7 million) in bilateral commercial exchange. Also, a 40,8\% increase was noted in the first half of 2019. There are 25 Polish companies in Uzbekistan and 15 companies represent the interests of Polish entrepreneurs ${ }^{17}$. In mutual relations there is observed increase of activity of the Embassy of Uzbekistan in Poland. It is discernible in numerous initiatives undertaken by the Uzbek Ambassador, HE Bakhrom Babaev, for the intensification of bilateral cooperation and popularization of reforms implemented in Uzbekistan, e.g. at the International Asian Congresses organized by Asia-Pacific Society in Torun and other conferences organized by the Department of Eastern Studies at the Faculty of Political Science and International Relations at the University of Warsaw. In bilateral relations there is also discernible increase of the Embassy's activity. The mutual economic cooperation is promoted e.g. by Sino-Polish Chamber of Commerce led by the former Deputy Prime Minister of Poland, Janusz Piechociński. In 2018 Polish-Uzbek Chamber of Commerce began its activity, supporting Polish companies in establishing business contacts through organizing conferences and economic missions.

The cooperation with Uzbekistan has been promoted for many years by "Poland-East" Association and the Association of Polish-Uzbek Friendship "Dustlik". All these activities produce concrete results. In 2019-2020 there was a significant increase in the number of people from Uzbekistan studying in Poland (over 1000). Currently, Polish universities open their branches in Tashkent and other Uzbek cities.

The President of Uzbekistan pays a lot of attention to the "economic diplomacy" and its efficiency. It is required by the reform strategy for 2017-2012. The success of the reforms vastly depends on it.

17 Data downloaded from the website of the Embassy of the Republic of Uzbekistan in Poland. Genesis of Poland-Uzbekistan economic relations and their development were analyzed in another study (Bodio, 2001). 
In the strategy it was assumed that the basic direction of foreign policy will be the region of Central Asia ${ }^{18}$. Its main goal is to build the strand of security and stability around Uzbekistan, establish good neighbor relations and to strengthen economic cooperation ${ }^{19}$. It is not an easy task, considering the amount of contentious problems that for have generated tensions, conflicts (e.g. for the access to water, energetic resources, borderlines, etc.) and even military incidents between countries in the region.

President Shavkat Mirziyoyev began his visits to the countries of Central Asia (Weitz, 2018; Кузьмина, 2018; Ионова, 2018; Как Узбекистан реализует..., 2015). The first one was in March 6-7, 2017, to Ashgabat (Интернет-Портал СНГ, 2018, April 24). The visit's effects were significant. There was signed a strategic partnership agreement, and there were solved border disputes. Also, there were adopted numerous agreements concerning Turkmen gas transit (e.g. building a gas main to China coming through Uzbekistan; participation of Uzbek companies in building "China - Central Asia" corridor; building "Uzbekistan Turkmenistan - Caspian Sea - Southern Caucasus" corridor).

On March 22, 2017, Shavkat Mirziyoyev paid another visit to Kazakhstan (Lentasng, 2017, May 20). During the visit there was signed a declaration on strengthening cooperation and neighbor relations. Negotiations were dominated by issues connected with the regulation of borders and trans-border, transport and communication cooperation, labor migration, liberalization of commercial exchange (lowering excise, simplifying procedures for export and import), opening border passes, eliminating visas and the results of the Aral Sea crisis. There was established a parliamentary cooperation.

Forum for Central Asia youth was organized as a part of Kazakh Days in Uzbekistan. In 2017 bilateral commerce values oscillated about USD 2 billion. It is forecasted that in 2020 their worth will reach USD 5 billion (Sputnik, 2018, August 31).

On September 5, 2017, Shavkat Mirziyoyev paid an official visit to Bishkek. The subject of the talks was e.g. economic cooperation, especially in energetic sector. However, the meeting was dominated mainly by other issues such as delimitation and demarcation of borders, where military incidents happened. There were adopted numerous agreements concerning trans-border cooperation (Eurasia Ekspert, 2017, September 8). The visit took place in March 9-10, 2018 in Tajikistan (Sputniknews, 2018, September 3). It was the first visit of Uzbek President to Dushanbe since 2000; quite a difficult one, considering the state of political-economic relations, border disputes and ones concerning building a hydroelectric station in Rogunsk, and ecological threats that can result from concluding the project. The visit however, was a breakthrough. There was reached an agreement on delimitation and demarcation of borders, and demining of some border parts. There was progress in

18 President confirmed the continuation of this direction of politics in his Address... of January 2020 (Постание Президента Республики Узбекистан, 2020)

${ }^{19}$ Uzbekistan borders with all Central Asia countries which is just another reason for such a choice for the main priority of foreign policy. 
solving the hydroelectric station dispute - there was formed a dedicated working group. Uzbekistan liberalized transit policy toward its neighbor by lowering barrier tariffs reaching $60 \%$, reestablished gas supplies, introduced facilities in the visa regime for people living in trans-border regions, and launched flight connections between the states' capital cities. In August, the President of Tajikistan came to Tashkent. The dialogue between the states is now continued.

From the current perspective it is clearly seen that Shavkat Mirziyoyev's redefinition of politics toward Central Asia states brings adequate benefits for the realized reform strategy. Establishing a constructive political dialogue with neighboring countries, relaxation of conflicts and tensions concerning "historical conflicts", border disputes, population flow, transit routes logistics, energetics, ecology and access to water, are key events having influence on changing the political atmosphere facilitating the integration of Central Asia. They generate beneficial conditions for enabling the development potential of the region. The contentious borders slowly become the "borders of friendship" which is visible in the dynamics of trans-border cooperation.

The effects of regional cooperation in recent years prove the rightness of a motto clearly discernible in Shavkat Mirziyoyev's politics that "cooperation is better than rivalry". B. Fazendeiro notices that the previous leader's traditional approach toward "power as domination" is countered by Mirziyoyev's approach to power as "soft power", understood as a rejection of confrontation in favor of implementing reforms for people. Integration in the region is supported by numerous Presidential initiatives. One of them is creating the institution of annual meetings for consultations between the heads of Central Asia states ${ }^{20}$. Another is creating forum for direct cooperation of authorities and businessmen at the regional level of Central Asia states. Also, Shavkat Mirziyoyev positively addresses the idea of establishing a common economic area with Kazakhstan and Kyrgyzstan. There are undergoing works for new visa regime ("Silk Visa") similar to Schengen Area. Countries from the region support the Chinese initiative "One Belt, One Road", want to make tourism an important branch of economy which requires joint actions in the matter of security (e.g. establishing integrated border management, fighting against extremism, terrorism, Islamic fundamentalism, money laundering, smuggling drugs and international organized crime).

20 The first meeting took place in Kazakhstan (2018), the second in Tashkent (2019), and the third is planned for Bishkek (2020). It is worth noting that on the second meeting there was noted "transition toward qualitatively new stage of regional dialogue at the highest level". 


\section{Concluding Remarks}

In 2019-2020 there were held elections to the Legislative Chamber ${ }^{21}$. Its Nurdinjon Ismoilov became its speaker and Professor Akmal Saidov became Ismoilov's first Deputy ${ }^{22}$. They were organized under the slogan "New Uzbekistan - New Elections". The elections are considered the most democratic ones so far. Later the President formed a new government which was accepted by the parliament ${ }^{23}$. Shavkat Mirziyoyev treated the elections as a "lesson of democracy", and mobilization of society in debates on the state's affairs, an increase of electoral culture and improvement of political atmosphere (Правда Востока, 2020, January 25). The elections were the turning point in the politics of recovering Uzbekistan for next ten years. They legitimized probably the most difficult stage of reforms, and gave a permission for their continuation. Challenges in that period are huge. Let me just recall the difficulties and late realization of some reforms and tasks included in the reform strategy or recommendations of the EU concerning the democratization of Uzbekistan's political system.

Still, it is not known in what direction will evolve the political system of Uzbekistan under the rules of Mirziyoyev. Experiences coming from hitherto transformation of this and other

21 The first round of elections took place in December 22, 2019; the second round - January 5, 2020. According to the data of the Central Election Commission of the Republic of Uzbekistan 53 out of 150 mandates were won by the Uzbekistan Liberal Democratic Party; 36 by the Uzbekistan National Revival Democratic Party “Milliy Tiklanish"; 24 by the Justice Social Democratic Party; 22 by the People's Democratic Party of Uzbekistan; 15 by the Ecological Party of Uzbekistan. Elections were organized by on new, liberalized Electoral Code. Candidates were elected based on single-member constituency; parties could submit non-partisan candidates; electoral campaign was financed on the same rules for all candidates, solely by public funds; observers could be not only the representatives of foreign missions but also the members of local self-governments, parties and organizations; competences of electoral commissions were extended in terms of examining complaints; and significantly increased the number of mandates for women. Interestingly, in these elections there was noted the lowest frequency among entitled voters since 1991. The members of the opposition were not allowed to vote. The Central Election Commission committed itself to implementing OSCE's recommendations into the electoral system.

${ }^{22}$ It is worth noting that the outstanding lawyer, political scientist and diplomat, A. Saidov, has cooperated with Polish political scientists in realizing research programmes, organizing conferences, etc. for many years (initially with the Institute of Political Sciences at the University of Warsaw). In 2012 together with A. Saidov we had a seminar and realized research programme entitled "Poland-Uzbekistan: Constitutions and Human Rights" (A. Saidov was then the Director of the National Human Rights Centre of the Republic of Uzbekistan; in 2015 a candidate in presidential elections. He actively participates in International Asian Congresses organized by prof. Joanna Marszałek-Kawa in Toruń.

23 The personal composition of government includes 27 persons (Prime Minister, his 1st Deputy, 3 2nd Deputies and 22 ministers (Законодательная палата..., 2019). It is worth noting that in the government there is a woman fulfilling the function of Deputy Prime Minister. Also, Eliar Ganiev became a member of government with whom I cooperated by the research project "Political Transformation of Uzbekistan" - its effect was a book "Uzbekistan. History-society-politics" - and at the presentation of the Polish edition of I. Karimov's book in Poznań, and other projects. 
countries in Central Asia taught to carefully form predictions in this respect (Bodio, 2007). Especially, because the subjective direction of socio-political life does not have to lead to democracy that is known in Europe. On the one hand, a similar opinion was presented by Roger Kangas who suggested "careful optimism in this respect" (Kangas, 2018). On the other hand, Edward Lemon is inclined to a view that the current transformation of Uzbekistan is "not democratization but an authoritarian update" or "authoritarian modernization". True democratization is possible only in the longer perspective (Lemon, 2019).

In the political biography of Shavkat Mirziyoyev there is a long period of activity in the previous ruling group which was declaring the democratization of socio-political life but in practice strengthened authoritarian solutions. He held, as observed, the exposed position of Prime Minister and was one of the closest cooperatives of Islam Karimov. That side of Mirziyoyev's biography is little known. Some observers of political life in Uzbekistan count Shavkat Mirziyoyev to the Samarqand clan. Therefore, he was expected to continue the political programme of the previous leader, which he initially declared. In time, however, it turned out differently, which confirmed his tactical abilities in the struggle for power. In a very short time he made radical changes in the system of power, dismantling many clanreligious linkages that have lasted for years. He has prohibited the cult of individual, and now gradually reduces anachronic mechanisms of clan politics and systemic pathologies connected to them (such as clientelism, corruption, abusing power, etc.).

Even before presidential elections he had underlined (and still does that) that his aim is the democratization of socio-political life and that there is no going back from democracy in Uzbekistan. Similar sentences were spoken by Mirziyoyev's predecessor, who at the same time was strengthening authoritarianism. However, the activities of Shavkat Mirziyoyev for now seem to confirm his will of liberalizing the political life. In three years of his presidency he has led to significant changes in the political system, especially in the separation of powers. The privileges of executive were limited, while the mechanisms of its control were extended. The same applies for judiciary and security services. Part of competences of the highest state authorities were transferred to regions which enhanced the meaning of self-governments in the structure of power.

The legislative and supervisory competences of parliaments were also extended. Since April 2019 deputies delegate Prime Minister and ministers, accept budget and listen to quarterly reports of Prime Minister on the government's activities. There were introduced elections of hokims. Partisan competitiveness was extended. The institution of ombudsman was created. Changes in judiciary are continued. The influence of executive on judiciary is limited. Courts are now financed by the appointed Supreme Court. The latter, after consultations with the President, appoints regional judges (previously it was a presidential prerogative). Administrative and economic courts were created. Judiciary supervision was strengthened for protecting civil rights and liberties by the state authorities, mainly by prosecutors and security services. The latter's lawlessness was limited. There are being created conditions for increasing activities of women in socio-political life. In July 2019, 
Tanzila Nartbaieva became a leader of Senate (according to the constitution she is now the second important person in the country $)^{24}$, and in January 2020 Elmira Basitchanowa was appointed as the Deputy Prime Minister.

For accusations of the lack of the opposition in the political life the President replied that he accepts it, as long as its representatives do not live abroad but in Uzbekistan and know the country's problems (Мирзиёев высказал..., 2019). The problem, however, is much more complicated, systemic and difficult to solve by e.g. partial freeing political prisoners.

The more detailed analysis of changes occurring in Uzbekistan clearly indicates that the political system of the country changes ${ }^{25}$. A huge role in the process of liberalization of this system is played by the President and his closest environment.

The type of exerting power by Shavkat Mirziyoyev in the last three years matches the model of transformational-autocratic leadership. The president is a leader-reformer. In his activities he oscillates between romanticism and political pragmatism. He has a long-term vision for the development of Uzbekistan, yet he is a realist. In the first days of his presidency he admitted that the time for reforms he was dreaming about has finally come (ANHOR. UZ, 2017). He was well-prepared for that role. He met the country and its problems, as well as mechanisms of power, and power distribution among political elites. For years, he has realized the scale of country's backwardness and prepared the programme of reforms.

In the leadership of Shavkat Mirziyoyev there is clearly seen patriotism. He treats his position as a mission to serve the nation and the state. As such, he shows strong determination to realize the reforms. He seems determined to realize the reforms. At one of the meetings he announced directly: "either I will fix everything or leave" (UPL.UZ Новости Узбекистана, 2017, December 22). He treats power not as a goal itself but a means for realizing the planned reforms.

The analysis of his speeches shows that he respects local traditions and at the same time cuts himself off the anachronic style of exerting power. He appreciates modern systems of governance and implements many of their elements in practice (such as "Digital Uzbekistan"). Fighting with conservatism and inertia in the structures of power, he changes Uzbekistan.

He can be self-critical in the contact with environment which is rare among the leaders of Central Asia countries. He inspires and motivates cooperatives to vast struggle, by evincing mobilizing and emphatic abilities. Considering the scale of tensions present in the realization of reforms, it may be assumed that he copes with stress as well.

24 In January 26, Tanzila Nartbaieva received a prestigious award of the "Person of 2019". It had been the first time when an Uzbek woman was awarded.

25 The try of explaining the leadership features of Shavkat Mirziyoyev was based on limited sources, mainly on the most important president's speeches, legal acts and media coverage about reforms. The available biographical data are limited in number. Official Uzbek websites lack properly elaborated profile of the leader. Therefore, the method applied in this study encounters many difficulties and risks. 
The President spares no criticism addressed to the highest state officers for mistakes in exerting power, delaying the realization of reforms and others. In his actions, autocratic methods of ruling mingle with democratic ones. He rules a hard hand to lead political elites to the creation of conditions for their constructive activity, and expects loyalty from the executive, as well as self-reliance and taking responsibility for their decisions.

He is a brave leader who is not afraid of risk. Some of his decisions may be recognized as nearly unsafe. For now, he aptly identifies threats of realized reforms. In this respect he has intuition and Instinct of "politician of blood and bones", which is evidenced by practice.

Also, he is a leader that acts systemically, evincing management skills in crisis situations. He is open to people and their problems. In the given context it should be emphasized that sensitivity to the problems of common people, care for rational politics of transformational "costs and benefits", and protection of the poorest are the canons of good leader-reformer. These lessons were taught during the first years of transformation in Poland and many other countries. In these transformations though, the huge costs of systemic, property and economic changes were borne by the common people while the benefactors were e.g. privileged and well-situated groups. Such situations lead to the distinction between "winners" and "losers", generate tensions and bad attitude toward reforms, and conflicts that lasts for years. Therefore, fight against political, bureaucratic and economic corruption is important as well.

Through his actions Shavkat Mirziyoyev tends to break out with social lethargy that was preserved for many ears, as well as with fear and reluctance to participation in political life. Through the institution of dialogue, he changes the language of politics and hitherto political communication channels. He pays great attention to the reconstruction of trust to state authorities and extension of the boundaries of the society's subjectivity. He gave an expression for that e.g. in January 2020, in the speech to the members of parliament by saying: "We have set a great goal which goes as follows: we will build new Uzbekistan along with our people. In this regard, the new idea «The society is an initiator of reforms» is further penetrating deep into our daily life activities" (Address by the President..., 2020).

He fluently uses socio-technique of exerting power; appreciates benefits coming from political marketing, cares for promotion and prestige of his country in the international arena. Dependently on the political contexts he is familiar with populistic activities. He works efficiently as a diplomat, which results in the successes in international relations.

Realized reforms prove that the President has the traits of transgressive leader, going beyond the known schemes of socio-political life in Uzbekistan.

His reforming activities gain recognition of the Uzbek society. According to the data of Public Opinion Center "Ijtimoiy Fikr" at the end of December 2019 88,9\% respondents indicated that the activity of the President helps to build the positive image of the country in the international arena; $83,4 \%$ expressed a conviction that there is undergoing liberalization; and $81,3 \%$ said that the reforms should be continued also in 2020 (Ижтимоий фикр, 2019, December 24). 
Summarizing, the conducted analysis of changes realized in Uzbekistan under the rules of Shavkat Mirziyoyev indicates that the President has started to write a new chapter in the history of independent Uzbekistan. The question about the next pages of history written by his action remains open. He has a great credit of social trust and it is important to use it wisely.

\section{References}

Address by the President of the Republic of Uzbekistan Shavkat Mirziyoyev to the Oliy Majlis. (2020, January). Retrieved from: https://www.un.int/uzbekistan/news/address-president-republic-uzbekistan-shavkatmirziyoyev-oliy-majlis-0.

Axbor UZ. (2019, Мау 25). Что происходит с проектом закона о госслужбе. Retrieved from: http://axbor. sorbon.ru/ru/Ctoproishoditsproektomzakonaogosslujbe_ru/.

Anhor UZ. (2017, December 22). Президент Мирзиёев выступил самокритично и жёстко, наметив кардинальные реформы. Retrieved from: https://anhor.uz/events/prezident-mirziyoev-vistupaetsamokritichno-zhyostko-nametiv-kardinalynie-reformi.

A World Bank Group Flagship Report. (2016).Doing Business 2016. Retrieved from: https://www.worldbank. org/en/events/2015/11/11/doing-business-2016-report.

Вестник Кавказа. (2020, January 27). Мирзиеев вывоодит Узбекистан в лидеры. Retrieved from: https:// vestikavkaza.ru/analytics/mirzieev-vyvodit-uzbekistan-v-lidery.html.

Власть. (2020, January 26). Послание Президента Республики Узбекистан Шавката Мирзиёева Олий Мажлису. Retrieved from: https://www.pv.uz/ru/newspapers/poslanie-prezidenta-respubliki-uzbekistan-shavkata-mirzieeva-olij-mazhlisu-2020.

Bodio, T. (2001).“Daleki-bliski Uzbekistan”. In T. Bodio (Ed.), Uzbekistan. Historia. - społeczeństwo-polityka. Warsaw: Elipsa.

Bodio, T. (2007). “Paradoksy polityki posttotalitarnej (na przykładzie Azji Centralnej)”. In M. Karwat (Ed.), Paradoksy polityki. Warsaw: Elipsa.

Bodio, T. (2001). “Polska-Uzbekistan: współpraca gospodarcza”. Boss-Gospodarka, 24, 24-27.

Bodio, T. (2018). "The origin and main trends of the evolution of the European Unions Policy in Central Asia". In T. Wallas, R. Fiedler, B. Przybylska-Maszner (Eds.), European Union and Central Asia. Cooperaqtion in Transition, Berln: Logos Verlag.

Bowyer, C.A. (2018, March). Political Reform in Mirziyoyev's. Uzbekistan:Elections, Political Parties band Civil Society. Central Asia-Caucasus Institute and Silk Road Studies Program, Silk Road Paper. Retrieved from: https://www.silkroadstudies.org/publications/silkroad-papers-and-monographs/item/13284-politicalreform-in-mirziyoyevs-uzbekistan-elections-political-parties-and-civil-society.html.

Buxgalter.uz. (2016, 7 December). Доклад Доклад избранного Президента Республики Узбекистан Шавката Мирзиёева на торжественном собрании, посвященном 24-й годовщине принятия Конституции Республики Узбекистан. Retrieved from: https://www.norma.uz/uz/vajnie_sobitiya/ obespechenie_verhovenstva_zakona_i_interesov_cheloveka_-_garantiya_razvitiya_strany_i_blagopoluchiya_naroda.

С Сарымсакова Ю. (2019). “Узбекистан: общественное мнение-2019”. Правда Востока, 258. Retrieved from: https://www.pv.uz/ru/newspapers/uzbekistan-obschestvennoe-mnenie-2019. 
CAAN Newtork. (2018, 13 December). Как Узбекистан реализует новую региональную политику?. Retrieved from: https://caa-network.org/archives/1484.

CentralAsia. (2018, 3 February). О чем говорит отставка главного чекиста Узбекистана, - эксперт. CentralAsia.media. Retrieved from: centralasia.media/news: $1429701 ? \mathrm{f}=\mathrm{cp}$.

CentralAsia (2019, 18 August). Президент Узбекистана назвал уровень чиновников главной угрозой. CentrAsia. Retrieved from: https://centrasia.org/newsA.php?st=1566129900.

Сейидов, А. (2016, 12 December). Человек в футляре. Кто стал временным президентом Узбекистан. Retrieved from: https://lenta.ru/articles/2016/09/12/sh_mirziyoyev/.

Самого страшного в Узбекистане человека лишили власти. Что теперь будет?. LENTA RU. Retrieved from: https://lenta.ru/articles/2018/03/02/grey_eminence/.

Саттаров, R. (2016, 7 September). Новое равновесие. Как Мирзиёев изменил кадровый состав власти Узбекистана. Московский Центр Карнеги. Retrieved from: https://carnegie.ru/commentary/72982.

EADaily. (2018, 31 January). Отставка главы СНБ Узбекистана — конец всесильного министра: эксперты. EADaily. Retrieved from: https:/eadaily.com/ru/news/2018/01/31/otstavka-glavy-snb-uzbekistanakonec-vsesilnogo-ministra-eksperty.

EADAILY. (2019, 29 January). В Узбекистане безработица среди молодежи превысила 17\%. Retrieved from: https://eadaily.com/ru/news/2019/01/29/v-uzbekistane-bezrabotica-sredi-molodezhi-prevysila-17.

Fazendeiro, T.B. (2018, 9 July). Soft power under Mirziyoyev: Change and continuty in Uzbekistan's foreign Policy. Retrieved from: https://www.opendemocracy.net/en/odr/soft-power-under-mirziyoyev/.

Эргашев, Б. (2018). Открытие Узбекистана. Итоги первого года президентства Шавката Мирзиёева. Retrieved from: https://eurasia.expert/otkrytie-uzbekistana-itogi-pervogo-goda-prezidentstva-shavkatamirziyeeva/.

Eurasia Ekspert. (2017, 8 September). Граница, логистика, ГЭС. О чем договорились Атамбаев и Мирзиёев. Retrieved from: https://eurasia.expert/o-chem-dogovorilis-atambaev-i-mirziyeev/.

Fergana Ru.news. (2020, January). Мирзиёев пообещал за пять лет довести ВВП Узбекистана до $\$ 100$ млрд (0). Retrieved from: https://fergana.ru/news/114373/?utm_source=yxnews\&utm_ medium=desktop\&utm_referrer=https $\% 3 \mathrm{~A} \% 2 \mathrm{~F} \% 2$ Fyandex.uz\%2Fnews).

Газета.uz. (2016, 19 October). Шавкат Мирзиёев утвержден кандидатом в Президенты от УзЛиДеП. Газета.uz. Retrieved from: https://www.gazeta.uz/ru/2016/10/19/uzlidep/.

Газета.uz. (2020, 23 January). В рейтинге демократии узбекистан занял 157-е место. Retrieved from: https://www.gazeta.uz/ru/2020/01/23/democracy/.

Gazeta.ru. (2016, 8 September). Премьер назначен президентом. Retrieved from: https://www.gazeta.ru/ politics/2016/09/08_a_10183475.shtml.

Гуманитарный Портал. (2019). Рейтинг стран мира по уровню демократии. Retrieved from: https:// gtmarket.ru/ratings/democracy-index/info.

Хакназаров, У. (2018, 14 January). Председатель СНБ Рустам Иноятов объявил о своей отставке. Ўзбекистон Халқ Харакати. Retrieved from: http://uzxalqharakati.com/ru/archives/15892.

Interkomitet.uz. (2020, 6 January). Шавкат Мирзиёев удостоен международной премии за вклад в возрождение тюркского мира. Комитет по межнациональным отношениям и дружественным связям с зарубежными странами при Кабинете Министров Республики Узбекистан. Retrieved from: http://interkomitet.uz/shavkat-mirzijoev-udostoen-mezhdunarodnoj-premii-za-vklad-v-vozrozhdenie-tjurkskogo-mira/.

Ижтимоий фикр. (2019, 24 December). Ижтимоий фикр: более 96\% узбекистанцев поддерживают президента страны Шавката Мирзиеева. Retrieved from: .https://mresearcher.com/2019/12/ izhtimoij-fikr-bolee-96-uzbekistantsev-podderzhivayut-prezidenta-strany- 
Ионова, Е. (2018), Внешнеполитические приоритеты Узбекистана. Retrieved from: imemo.ru^files/ File/magazines/rossia_i_novay/2018.

ИНТЕРНЕТ-ПОРТАЛ СНГ. (2018,24 April). Узбекистан - Туркменистан: новый этап сотрудничества. Retrieved from: https://e-cis.info/news/566/61965/P.

Kangas, R. (2018). "Reform and Change in Uzbekistan". Poliy Paper, 2. Retrieved from: www.osce-academy. net > upload > file > Reform-a.

Кучкаров, Д. (2020). Из 13 млн. трудоспособньх людей налог платят лишь 4,6 млн. Retrieved from: https://uzreport.news/society/djamshid-kuchkarov-iz-13-mln-trudosposobnih-lyudey-nalog-platyatlish-4-6-mln.

Кузьмина, Е. (2018).“Проблемы экономического единства Центрально-Азиатского региона”. Проблемы национальной стратегии, 4(49).

KB. (2020, 28 January). Расходы госбюджета Узбекистана в 2019 году выросли более чем на треть. Retrieved from: https://rossaprimavera.ru/news/8a865a4b.

Корнилова, Л. (2018, 5 January). Президент Узбекистана вошел в ТОП мировых лидеров, меняющих современньй мир. Retrieved from: https://www.podrobno.uz/cat/obchestvo/prezident-uzbekistanavoshel-v-top-mirovykh-liderov-menyayushchikh-sovremennyy-mir/.

Конституция Республики Узбекистан, Retrieved from: http://constitution.uz/.

Кутбитдинов, Ю. (2019). “Стратегия действий в инвестиционных показателях”. Экономическое обозрение, 9(237). Retrieved from: https://review.uz/ru/post/staty/trendi/strategiya-deystviy-vinvestitsionniyx-pokazatelyax.

Kun.uz/ru. (2018, 5 Мау). Мирзиёев заявил, что экономика находится в тяжелом положении. Retrieved from: https://kun.uz/ru/news/2018/05/20/mirzieev-zaavil-cto-ekonomika-nahoditsa-v-tazelompolozenii.

Kun.uz. (2020, 27 January). Танзила Норбоева: Ўзбекистонда 5 миллион ахуоли камбавалликда хуаёт кечирмоқда. Retrieved from: ttps://kun.uz/news/2020/01/27/tanzila-norboyeva-ozbekistonda-5-millionaholi-kambagallikda-ha yot-kechirmoqda

Lemon, E. (2019, June). Mirziyioyev's Uzbekistan; Democratization or Authoritarian Upgrading. Foreign Policy Research Institute, Eurasia Program, Central Asia Papers.

Lentasng. (2017, 20 Мау). Государственный визит Президента Узбекистана в Казахстан. Retrieved from: https://lentasng.info/show/1/7569/gosudarstvennyj-vizit-prezidenta-uzbekistana-v-kazahstan.

Lex UZ. (2017, 1 March). Указ Президента Республики Узбекистан О дальнейшем совершенствовании деятельности Администрации Президента Республики Узбекистанг Национальная база данных законодательства. Retrieved from: https://lex.uz/docs/3130383.

LexUZ. (2016, 17 September). “Об органах внутренних дел”. LexUZ, LexUz, газете «Народное слово», 184 (6589). Национальная база данных законодательства. Retrieved from: https://lex.uz/docs/3027845.

LexUZ. (2017). Указ Президента Республики Узбекистан О Стратегии действий по дальнейшему развитию Республики Узбекистан. LexUZ on-lain. Retrieved from: https://lex.uz/docs/3107042.

LexUZ. (2018, 6 April). Закон Республики Узбекистан О Службе государственной безопасности Республики Узбекистан. Национальная база данных законодательства. Retrieved from: https:// lex.uz/docs/3610937.

LexUZ. (2017, 8 September). Указ Президента Республики Узбекистан Об утверждении Концепции административной реформы в Республике Узбекистан. Национальная база данных законодательства. Retrieved from: https://lex.uz/docs/3331176 Указу.

LexUZ. (2018, 10 January). Об Оборонной доктрине Республики Узбекистан 10.01.2018 г. Национальная база данных законодательства. Retrieved from: https://lex.uz/docs/3495906. 
LexUZ. (2019, 3 October). Указ Президента Республики Узбекистан О мерах по кардинальному совершенствованию кадровой политики и системы государственной гражданской службы в Республике Узбекистан. Retrieved from: https://lex.uz/docs/4549993.

Lex.Uz. (2019, 10 December). Постановление Президента Республики Узбекиста О мерах по дальнейшему сокращению бюрократических барьеров и внедрению современных управленческих принципов в деятельность государственных органов и организаций. Национальная база данных законодательства. Retrieved from: https://lex.uz/ru/docs/4634625.

Lex.Uz.(2019,31 October). Постановление Президента Республики Узбекистан О внедрении качественно новой системы организации работы Правительства Республики Узбекистан. Национальная база данных законодательства. Retrieved from: https://nrm.uz/contentf?doc=577449_\&products=1_ vse_zakonodatelstvo_u-zbekistana.

Махалля - государство в одном квартале. (2016). Retrieved from: https://uz.sputniknews.ru/society/20160107/1495295.html.

Meliev, Kh. (2019, 13 December). Investment Climate in The Republic of Uzbekistan: Current State, Challenges and Solutions Investments - Driver Of Economic Growth. Paper shared by the Embassy of Uzbekistan in Poland.

Migrant INFO. (2019, 24 November). Минимальная и средняя зарплата в узбекистане в 2020 году. Retrieved from: https://tabin.ru/deportatsiya/minimalnaya-i-srednyaya-zarplata-v-uzbekistane-v2020-godu.html.

МИД Узбекистана (2019, 31 December). Retrieved from: https://mfa.uz/ru/press/news/2019/12/22767/.

Мирзиёев, Ш. (2017, 16 January). Критический анализ, жесткая дисциплина и персональная ответственность должны стать повседневной нормой в деятельности каждого руководителя. Retrieved from: ttps://novosti-uzbekistana.ru/shavkat-mirziyoev-kriticheskij-analiz-zhestkaya-disciplina-i-personalnaya-otvetstvennost-dolzhny-stat-povsednevnoj-normoj-v-deyatelnosti-kazhdogo-rukovoditelya/.

Муминов, А. (2016, 10 September). Преемника Каримова определили без конституции. Retrieved from: https://inbusiness.kz/ru/news/preemnika-karimova-opredelili-bez-konstitucii.

Nation News, (2016, 8 September). Игра узбекских престолов: Шавкат Мирзиёев станет новым президентом Узбекистана. NATION NEWS. Retrieved from: https://nation-news.ru/212729-igrauzbekskih-prestolov-shavkat-mirzieev-stanet-novym-prezidentom-uzbekistana.

Народное слово. (2019, 14 March). Президент Узбекистана Шавкат Мирзиёев был награжден премией StrategEast Westernization. Официальный канал онлайн-издания Народное слово. Retrieved from: http://xs.uz/ru/post/prezident-uzbekistana-shavkat-mirziyoev-byl-nagrazhden-premiej-strategeast westernization-2018.

Народное слово. (2017, 4 January). “Закон О противодействии коррупици”. Народное слово, 2 (6666). Retrieved from: https://lex.uz/docs/3088013.

Новости Узбекистана. (2019, 19 December). Узбекистан стал страной года по версии. The Economist. Retrieved from: https://nuz.uz/sobytiya/45316-uzbekistan-stal-stranoy-goda-po-versii-the-economist. html.

Новости Узбекистана. (2019, 10 April). Премию «Человек года в Азии» вручат Шавкату Мирзиёеву на медиа-форуме АJА. Новости Узбекистана. Retrieved from: https://nuz.uz/politika/40084-premiyuchelovek-goda-v-azii-vruchat-shavkatu-mirzieevu-na-media-forume-aja.html.

Новости Узбекистана. (2020). Госкомстат Узбекистана зафиксировал замедление роста цен в экономике в 2019 году. Retrieved from: https://nuz.uz/ekonomika-i-finansy/46329-goskomstat-uzbekistanazafiksiroval-zamedlenie-rosta-cen-v-ekonomike-v-2019-godu.html. 
Новости Узбекистана. (2020,3 February). Президент Узбекистана предложил создать Министерство по делам махалли и семьи. Retrieved from: https://nuz.uz/obschestvo/46760-prezident-uzbekistanapredlozhil-sozdat-ministerstvo-po-delam-mahalli-i-semi.html.

Панкратенко, И. (2017). Шавкат Мирзиеев: 100 дней в первом кресле Узбекистана. Retrieved from: https://narzur.ru/shavkat-mirzieev-100-dney-v-pervom-kresle-uzbekist/.

Правда Востока. (2020, 25 January). “Послание Президента Республики Узбекистан Шавката Мирзиёева Олий Мажлису”. Правда Востока, 19. Retrieved from: https://iibb.uz/ru/news/Ozbekiston-respublikasiprezidenti.

Президент Узбекистана предложил создать Министерство по делам махалли и семьи. (2020). Retrieved from: https://nuz.uz/obschestvo/46760-prezident-uzbekistana-predlozhil-sozdat-ministerstvopo-delam-mahalli-i-semi.html.

RepostUZ. (2020, 20 January). Названа сумма освоенных Узбекистаном инвестиций в 2019 году. Retrieved from: https://repost.uz/spasibo-bratya.

Review. (2020, 27 January). В Узбекистане количество бедных составляет 5 млн человек. Retrieved from: https://review.uz/ru/news/technology/society/v-uzbekistane-kolicestvo-bednyh-ludej-sostavlaet-5-mln celovek.

Rambler.ru.(2016, 14 December). Мирзияев официально стал президентом Узбекистана. Retrieved from: https://news.rambler.ru/cis/35558478-mirziyaev-ofitsialno-stal-prezidentom-uzbekistana/.

Росбалт.RU. (2017, 11 July). Опрос: Половина населения Узбекистана испытывает проблемы с водоснабжением и недовольна работой госорганов. Retrieved from: https://www.rosbalt.ru/ world/2017/07/11/1629650.html.

Reviw.uz. (2019, December). По итогам 2019 года внешнеторговый оборот Узбекистана составил \$42 млрд. Retrieved from: https://review.uz/post/po-itogam-2019-goda-vnesnetorgovyj-oborot-uzbekistanasostavil-42-mlrd.

Regulation.gov.uz. (2019, 22 October). Постановление Президента Республики Узбекистан. Концепция комплексного социально-экономического развития Республики Узбекистан до 2030 года. Retrieved from: regulation.gov.uz, 22/10/2019,https://regulation.gov.uz/ru/document/8839.

РЕСПУБЛИКА УЗБЕКИСТАН КОНСУЛЬТАЦИИ 2019 ГОДА В СООТВЕТСТВИИ СО СТАТЬЕЙ IV - ПРЕСС-РЕЛИЗ И ДОКЛАД ПЕРСОНАЛА. Retrieved from: https://yandex.ru/clck/ jsredir?bu=91lt34\&from $=$ yandex.

Sputnik news. (2020, 13 February). Биография президента Узбекистана Шавката Мирзиёева. Sputnik. Retrieved from: https://tj.sputniknews.ru/world/20141125/1013384302/shavkat-mirziyoyev-uzbekistanprezident.html.

Sputnik news.ru/asia. (2016, 8 September). Врио президента Узбекистана утвержден премьер Шавкат Мирзиёев. Retrieved from: https://tj.sputniknews.ru/asia/20160908/1020621854.html.

Sputnik. (2018, 31 August). Узбекистан и Казахстан хотят к 2020 году выйти на товарооборот в $\$ 5$ млрд. Retrieved from: https://uz.sputniknews.ru/economy/20180831/9281635/uzbekistan-kazahstantovarooboro.

Spot. (2019, 14 February). Узбекистан успешно разместил первые в своей истории еврооблигации на $\$ 1$ млрд. Retrieved from: https://www.spot.uz/ru/2019/02/14/eurobonds-uzb/.

Sputnik news. (2018, 3 September). Президент Узбекистана в Таджикистане: первые итоги исторического визита. Retrieved from: https://ru.sputniknews.kz/Asia/20180309/4858798/uzbekistan-tajikistanpresident-visit.html.

Star, S.F. (2018). Change and Continuity in Uzbekistan, 1991-2016. Uzbekistan's New Face. Rowman \& Littlefield Publishers. Retrieved from: https://www.isdp.eu/publication/uzbekistans-new-face/. 
Sprawozdanie w sprawie zalecenia Parlamentu Europejskiego z dnia 26 Marca 2019 roku dla Rady, Komisji i wiceprzewodniczacej Komisji/wysokiej przedstawiciel Unii ds. zagranicznych i polityki bezpieczeństwa w sprawie nowej kompleksowej umowy między UE a Uzbekistanem. Retrieved from: https://www.europarl. europa.eu/doceo/document/A-8-2019-0149_PL.html.

Sever, M. (2018). Judicial and Governance Reform. Central Asia-Caucasus Institute and Silk Road Studies Program, American Foreign Policy Council. Retrieved from: https:/www.silkroadstudies.org/publications/ silkroad-papers-and-monographs/item/13282-judicial-and-governance-reform-in-uzbekistan.html.

Star, S.F., Cornell, S. (2018). Uzbekistan's New Face. Rowman \& Littlefield Publishers. Retrieved from: https:// www.isdp.eu/publication/uzbekistans-new-face/.

TACC. (2016, 2 September). Узбекистан: расклад сил после смерти Каримова. TACC. Retrieved from: https://tass.ru/mezhdunarodnaya-panorama/358824.

The World Bank. (2020). Doing Business 2020. Reports. Retrieved from: ttps://www.doingbusiness.org/en/ reports/global-reports/doing-business-2020.

TAG nеws uz. (2018, 28 August). Мирзиеев реформировал аппарат президента Узбекистана. ТАG news. Retrieved from: https://uztag.info/ru/news-of-the-day/mirzieev-reformiroval-apparat-prezidentauzbekistana.

Tashkent Times. (2017, 8 February). “Uzbekistan's Development Strategy for 2017-2021 has been adopted following public consultation".

Tsereteli, M. (2018). The Economic Modernization of Uzbekistan. Central Asia-Caucasus Institute and Silk Road Studies Program, Silk Road Paper. Retrieved from: silkroadstudies.org > 2018-04-Tsereteli-Uzbekistan.

UZREPORT WORLD. (2020, 22 January). Законодательная палата утвердила новых заместителей Премьер-министр. Retrieved from: https://uzreport.news/politics/zakonodatelnaya-palata-utverdilasostav-novogo-kabineta-ministrova.

UPL 24, UZ, Новости Узбекистана. (2017,24 December). Шавкат Мирзиёев: «Либо я все исправлю, либо я уйдy». Retrieved from: https://upl.uz/president/4039-news.html.

UzNews. (2019, 1 November). На социильное обеспечение из бюджета в 2020 году выделят более 66 триллионов сумов. Retrieved from: https://uznews.uz/ru/article/17543.

Uz News. (2020, 20 January). Сколько инвестиций освоил Узбекистан в 2019 году?. Retrieved from: https:// novosti-uzbekistana.ru/skolko-investicij-osvoil-uzbekistan-v-2019-godu/.

Uzbekistan National News Agency. (2020, 25 January). Послание Президента Республики Узбекистан Шавката Мирзиёева Олий Мажлису. Retrieved from: http://uza.uz/ru/politics/poslanie-prezidentarespubliki-uzbekistan-shavkata-mirziyeev-25-01-2020.

Uzbekistan Natioonal News Agency. (2020, 25 January). Послание Президента Республики Узбекистан Шавката Мирзиёева Олий Мажлису. Retrieved from: http://uza.uz/ru/politics/poslanie-prezidentarespubliki-uzbekistan-shavkata-mirziyeev-25-01-2020.

Uzbekistan - Toward, a New Economy: Country Economic Update. Retrieved from: http://documents. vsemirnyjbank.org/curated/ru/86650156257267569/Uzbekistan-Toward-a-New-Economy-CountryEconomic-Update.

Weitz, R. (2018). “Uzbekistan's Foregin Policy: Change and Continuity under New Leadership". Central Asia-Causasus Institute Silk Road Studies Program. Silk Road Paper. Retrieved from: silkroadstudies. org > SilkRoadPapers > 1801Weitz.

ZNews. (2019, 11 October). С 2020 года чиновников и членов их семей обяжут отчитьваться о своих доходаx. Retrieved from: https://uznews.uz/ru/article/17257. 